\title{
Why Was It the Ming Dynasty that Engendered the Guanxi Motif in Fiction?
}

\author{
RUIHUI HAN
}

\begin{abstract}
Compared to other informal social network mechanisms, guanxi is more common in China and is the most typical. Even in daily life, it is indispensable. Hence, in Chinese fiction, the guanxi motif is prevalent and important. Interestingly, before the Ming dynasty, guanxi was not a literary motif in fiction. This article suggests that three factors contributed to the rise of the guanxi motif in fiction in the Ming dynasty. The first was the boom in fiction writing, especially in the genre of realism, that occurred in this era, which expanded the scope of literary representation. The second was the degradation of public morals in the Ming dynasty, a momentous social transition that Ming fiction writers noted and portrayed. Guanxi, as a disruptive social mechanism that dismantled previous models of human connection, became a focus in their works. The third was the fact that the atmosphere of money worship promoted by guanxi, together with official corruption, facilitated widespread social inequality. Guanxi, as the crux of inequity, inspired writers to expose social turpitude. More importantly, the guanxi motif satisfied the need for plot conflict in literary works. Thus, it became a necessary motif in Ming fiction.
\end{abstract}

Keywords: guanxi; the Ming dynasty; fiction; Confucianism; informal social network

In both Outlaws of the Marsh and The Plum in the Golden Vase, written during the Ming dynasty (1368-1644), the semiliterate villain Ximen Qing, without proficiency in management or skill in production, earns high social status and abundant wealth. In Outlaws of the Marsh, "[t] he whole county treated him with careful deference" (Shi 1986: 192). In The Plum in the Golden Vase, "everyone in the whole district was rather afraid of him", although "[i]t is scarcely likely that such a person should not turn out to be a man of some property" (LanlingXiaoxiaoSheng 2013: 53).

The magic weapon assisting his rise is guanxi (关系), a common and ubiquitous social network in China. Although Ximen Qing is semiliterate and has no substantial knowledge of production, he is adept at guanxi. His social role as a go-between allows him to influence law, politics, and commercial and 
HAN

other social activities. Though decadent and dissolute, this villain is able to achieve success and is treated with deference and fear by others.

Guanxi is so significant in Chinese society that without it, nothing can be done (Ju 1995: 231). Bian (2018) states that guanxi is becoming increasingly important in contemporary China. It has existed in China for approximately two thousand years, having originated from Confucianism (Luo, Huang, \& Wang, 2012: 142), which emerged in China in approximately 500 BC and has been present in Chinese society "for more than two thousand years" (Zhang \& Zhang 2006: 375). Confucianism defines the individual as a social relational being (Farh, Tsui, Xin, \& Cheng 1998: 473) imbedded in a system of interdependence (Hitt, Lee, \& Yucel 2002: 358). Therefore, one should act in accordance with one's relationship to others (X.-P. Chen \& Chen, 2004: 307). This emphasis on relationships causes systems of special favors or reciprocity to form within specific circles or between certain individuals.

Guanxi is a type of informal social network (Horak \& Taube 2016: 596). Such networks exist in many societies, with examples including blat in Russia (Ledeneva 2003), wasta in the Arab world (Brandstaette 2011), yonggo in South Korea (Horak \& Klein 2016), tapsh in Azerbaijan (Aliyev 2017), and sifarish in Pakistan (Nadeem \& Kayani 2017). As guanxi is prevalent in China and will persist and even increase in importance there (Bian 2018), the concept is attracting significant academic attention in the fields of management, sociology, economics, and marketing; however, it has not gained due recognition in literary studies.

\section{Rise of the guanxi motif in Ming fiction}

The rise of the guanxi motif in Ming fiction can be traced through the "four marvelous masterpieces” (四大奇书) of the Ming dynasty, which also represent the crowning achievements of ancient Chinese fiction writing. These four masterpieces are Outlaws of the Marsh, The Romance of the Three Kingdoms, Journey to the West and The Plum in the Golden Vase.

To explain the importance of the guanxi motif in Ming fiction, it is necessary to investigate the three dimensions of guanxi (Hwang 1987; Yen, Barnes, \& Wang 2011). The first is emotional attachment (ganqing 感情), which refers to "the degree of emotional understanding, connections and the sharing of feelings of happiness and fears alike" and "a sense of loyalty and solidarity, the willingness to take care of each other under all circumstances" (X.-P. Chen \& Chen 2004: 314). The second is personal obligation (renqing 人情), which is regarded as “[t] he special treatment of an individual, the allocation of resources to another party as a 'gift' in the process of a market 
Why Was It the Ming Dynasty that Engendered the Guanxi Motif in Fiction?

transaction, to tighten up the bonds between parties" (Leung \& Wong 2001: 13). The third is face (mianzi 面子), which refers to impression management engaged in to ensure acceptance as a member of a given group (Zhai 2011: 93) and which can obligate people to return favors and take responsibility (Wong, Leung, Hung, \& Ngai 2007: 878). Particularism is fostered by each of the three dimensions (Bian 2018: 8).

The three dimensions of guanxi effectively structure the plots of the "four marvelous masterpieces". Mianzi and renqing among the heroes are recurrent factors in Outlaws of the Marsh. Without mianzi and renqing, Song Jiang, the protagonist of Outlaws of the Marsh, would not have been able to escape criminal punishment, not to mention the further plot. Because Song Jiang has good guanxi with the magistrate, he is released without punishment after he kills Yan Po Xi. As an escaped prisoner, Song Jiang is generously accommodated and sheltered by Chai Jin, who earns considerable renqing for his deeds. When Song Jiang meets Wu Song, another escaped prisoner, he asks Chai Jin to provide new clothes for Wu Song. Although Chai Jin dislikes Wu Song, he agrees to this without reluctance for the sake of Song Jiang's mianzi. In the process, Chai Jin earns renqing and mianzi from Song Jiang and $\mathrm{Wu}$ Song; Song Jiang also earns them from Wu Song. Therefore, when Chai Jin is persecuted later, the heroes he has helped, including Song Jiang and Wu Song, save him. This renqing and mianzi also build Wu Song's loyalty to Song Jiang. All the heroes in Outlaws of the Marsh are involved in a complicated network of guanxi. They owe each other mianzi and renqing.

The ganqing of the protagonists in The Romance of the Three Kingdoms, the three sworn brothers Liu Bei, Guan Yu and Zhang Fei, is the basis of the plot in this work of fiction. Because of ganqing, Liu Bei, Guan Yu, and Zhang Fei consolidate their efforts and thereby achieve great feats in battle, allowing them to establish the Shu kingdom. The "three kingdoms" situation ultimately unfolds through splendid stories centered on the men's ganqing. Ganqing also motivates Liu Bei to immediately avenge Guan Yu, who is decapitated by the $\mathrm{Wu}$. His obviously irrational and rash decision to wage war against the $\mathrm{Wu}$ causes a fiasco, ushering in the end of the "three kingdoms" and the denouement of the plot of The Romance of the Three Kingdoms.

Journey to the West satirizes guanxi and the chaotic political condition of feudal society. In this work, deities or potentates protect each other through mutual guanxi. Legal justice is nothing but a toy that they manipulate at their whim. Because of their guanxi with the deities, the demons commit unscrupulous deeds without being punished. Such plotlines are so common in this novel that they form the basis of most of the relatively independent sections of this work: repeatedly, the four pilgrims encounter and defeat demons only 
to find that the demons are the disciples or subordinates of gods. In other words, the demons obtain mianzi from the deities, and punishing them means hurting divine mianzi. In other words, the demons are empowered by mianzi obtained from the deities they are affiliated with. Guanxi enables the demons to have those deities as their kaoshan (靠山, patron). Justice cannot be realized in such a topsy-turvy world. For example, the ghost of the kingdom of Wuji, who is murdered by a monster, cannot obtain justice against the murderer because the murderer has good guanxi with other potentates: "[h]e's always drinking with the city god, and he's connected with all the dragon kings. The Heaven-equaling God of Mount Tai is a friend of his, and all the Ten Kings of the Underworld are his sworn brothers. We have nowhere to turn if we want to bring a case against him" (C. Wu 1984: 93). Guanxi, as an informal social network, replaces the normal political order and legal justice.

The Plum in the Golden Vase describes guanxi's function in commercial life, officialdom and daily life. In these domains, Ximen Qing, the town villain and protagonist of the novel, rises to high social status and gains abundant wealth through guanxi. Compared to the three abovementioned works, this novel uses a more realistic mode to expose contemporary society. As C. T. Hsia describes, "[It] has departed from history and legend to treat a world of its own creation, peopled by life-sized men and women in their actual bourgeois surroundings divested of heroism and grandeur" (Hsia 2016: 166). The axis of all social connections in The Plum in the Golden Vase is Ximen Qing. Ximen Qing's social connections exist as guanxi, a web linking the worlds of family, commerce and officialdom. Through gifts and banquets and by devoting himself to Cai Jing, a powerful and wicked minister, as his adopted son, Ximen Qing establishes and maintains stable guanxi with potentates. Soon, he becomes a parvenu. The plot of The Plum in the Golden Vase is structured around the mechanism of Ximen Qing's guanxi. With his demise, his family, wealth, ganqing, renqing and mianzi quickly dissipate into nothing, and the novel ends.

It is interesting to note that perceptions of guanxi in the four abovementioned novels develop chronologically. In Outlaws of the Marsh, the earliest work, guanxi is regarded as a way for the heroes or heroines to accomplish their feats. In The Romance of the Three Kingdoms, guanxi among the protagonists is extolled. However, in the later works of fiction, Journey to the West and The Plum in the Golden Vase, guanxi is deemed a diabolical and infamous social network used to procure undeserved profit.

Although it is prevalent in Ming fiction, the guanxi motif was scarce in fiction prior to this period. None of the fiction from the Wei and Jin dynasties (220 AD-420 AD) to the Yuan dynasty (1271 AD-1368 AD) used the guanxi 
Why Was It the Ming Dynasty that Engendered the Guanxi Motif in Fiction?

motif. Only in the Ming dynasty did the guanxi motif begin to play a significant role in works of fiction.

Factors engendering the guanxi motif in the Ming dynasty

The Ming dynasty witnessed a different social ethos and economic and political situation than previous dynasties and saw an upswing in fiction writing. All these factors contributed to the rise of the guanxi motif in Ming fiction.

Promotion of the fiction genre and the guanxi motif in the Ming dynasty

Unlike the early forms of European literature, the earliest forms of Chinese literature from the pre-Qin dynasty were lyric, not narrative. Ancient Chinese literature has a strong tradition of lyricism and emotive writing (G. Chen, 2015). Moreover, "Chinese language is a good medium for poetry" (J. S. Wu, 1969). Therefore, fiction, as a narrative genre, maintained its marginalized status until the Ming dynasty. The Chinese word for "fiction" is "xiaoshuo" (小说), which means “lesser discourse" or "petty talk" without a reliable origin (L. H. Wu 1995: 340). The term first appeared in Zhuangzi's (369 BC-286 BC) masterpiece Wai Wu (“外物”), in which Zhuangzi states that if one polishes xiaoshuo to obtain reputation and honor, one will be far from true wisdom (Zhuangzi 2001: 129)(饰小说以干县令, 其于大达亦远矣). This statement indicates that xiaoshuo refers to frivolous speech that departs from great truth. Xiaoshuo, or fiction, had a marginalized status in Chinese literature and was not regarded as a formal genre before the Ming dynasty.

The Ming dynasty witnessed the growth of fiction. The lowered costs of paper and woodblock carving with advances in technology decreased the price of imprinting and ultimately led to a publishing boom (Brokaw \& Chow 2005: 78-81). This contributed to the publication of fiction. The flourishing of Ming fiction is demonstrated not only by the increased number of authors, works and subgenres of fiction but also by the originality of fictive works. Compared to works about anecdotes, mysteries, and legends, which drew plots from the stories spread among the folk, many works of fiction in this period were independent creations of the literati. The life scope they reflected was also expanded through the enhanced use of realism. For example, The Romance of Three Kingdoms, Outlaws of the Marsh, Journey to the West and The Plum in the Golden Vase all exceeded previous works of fiction in both length and degree of realism, and realism was also reinforced in the literary theory of the Ming 
HAN

dynasty, as works violating the principle of realism were incisively criticized (Han Tongwen \& Huang Lin 1980).

The emphasis on realism motivated authors to underscore conflict in fiction. Many theorists and fiction writers have stated that conflict is critical to plot creation in fiction. For example, William H. Coles stated that "Conflict is the essence of drama, and all literary fiction requires drama to please the reader and to succeed as a story" (Coles 2016). Kurt Vonnegut also claimed that a story is about a character getting into and then getting out of trouble (Vonnegut 2010). In the fiction written before the Ming dynasty, the conflicts were simple and small in scale or not connected to the social reality. However, beginning with the Ming dynasty, works of fiction became longer and portrayed more violent conflicts and a broader social context.

Guanxi is a fundamental cause and catalyst for conflict in fiction. Although guanxi is a quotidian matter, it is a social mechanism responsible for social inequity and unfairness, as it seeks particularism or special favors and obtains an advantage at the price of social loss (Warren, Dunfee \& Li 2004); thus, it satisfies the need to establish conflict in fiction. In the Ming dynasty, the fiction genre, especially realist fiction, burgeoned. Naturally, the guanxi motif took the center of the literary stage as a critical factor for stirring up conflict and developing plots. A unique subgenre of the Ming dynasty, human relations fiction (renqing xiaoshuo, 人情小说), even came into being.

Public morals of interpersonal relationships and guanxi representation in Ming fiction

The Ming dynasty, especially the late Ming dynasty, witnessed dramatic social moral deterioration in interpersonal relationships. Confucianism had defined principles for interpersonal relationships. However, during this era, these fundamentals were gradually forsaken.

In Confucianism, human relationships should be conducted in accordance with the principle of ren (仁) and respect for the social hierarchy. Ren means benevolence, goodness, humaneness or humanitarianism. Confucianism holds that an individual is not a morally autonomous individual but is a social being whose identity derives from his or her connection with others in the human community. Therefore, one should act with goodness, or humaneness, toward others and all human beings when possible. The concept of ren is an elementary requirement for human connection.

Adhering to the duties of the hierarchy is another principle of Confucianism related to human relationships. “Junjun, chenchen, fufu zizi” (君君, 臣臣, 父 父, 子子) is a famous expression of this principle. It can be translated as "[1] 
Why Was It the Ming Dynasty that Engendered the Guanxi Motif in Fiction?

et the ruler be a ruler; the subject, a subject; the father, a father; the son, a son" (Confucius 2007: 82). In other words, the ruler should act in accordance with the duties of a ruler, and the subject with the duties of a subject; the father should act according to his dignity, and the son should act according to his role. Thus, social individuals should act in accordance with their roles, duties and identities.

Based on the two abovementioned principles, there are other requirements for human relationships in Confucianism. Among these, sangang wuchang (三纲五常) and sancong side (三从四德) are representative. Sangang wuchang (三纲五常) (the three cardinal guides and the five constant virtues) is composed of sangang, which means guides for the relationship between emperor and minister, father and son, or husband and wife, and wuchang, which refers to the virtues of ren (仁 humaneness), yi (义 righteousness), li (礼 etiquette), $z h i$ (智 wisdom) and $x$ in (信 integrity).

Sancong side (三从四德, three obediences and four virtues) is a behavior standard for women. It is composed of sansong, which refers to women's subordinate position to men - their obedience to their fathers when they are maiden daughters, to their husbands when they are wives and to their sons when they are widowed - and side, which means that women should exhibit the virtues of good morality, proper speech, modest manners and diligent and skillful work in the family.

However, historical records kept by the literati in the Ming or later dynasties indicate that the Confucian principles for human relationships were discarded as moral degradation took hold. For example, Li Chunfang, the zhuangyuan ${ }^{1}$ in 1547 and a prime minister in the Ming dynasty, recorded that in Hangzhou, a thriving commercial city, a "frivolous mood permeates society; modest and honest ethos vanishes; the hierarchal order of the older and younger is abandoned” (人多轻薄之习, 无谦厚之风, 长幼失序)(Li Chunfang 2014: 156). He Qiaoyuan, a historiographer in the Ming dynasty, noted that in the countryside, "people got together because of wealth and split up because of misfortune and hatred” (聚为货媒, 散为祸仇), and “adjacent families were jealous of each other” (比族忌姤) (He Qiaoyuan, 2004). Gu Yanwu, a philologist and philosopher active during the transition between the Ming and Qing dynasties, lamented that "at present, there are three paradoxes in the ways of human connection: the more modest on the surface indicates the more hypocritic; the more intimate on the surface means the more shallow; the more

1 The zhuangyuan was the man who achieved the highest score on the highest imperial examination in feudal China. 
luxury on the surface means the more stingy” (今日人情有三反, 曰: 弥谦弥 伪, 弥亲弥汛, 弥奢弥文) (Gu Yanwu 2014: 315).

Records of family relations forcefully reflect changes in the era's ethos. The Ming dynasty writer Xie Zhaozhe noticed that the daughters of wealthy families had deteriorated morals, as evidenced by their pride, luxury, debauchery, and idleness, and were wiseacres in the houses of their husbands, frequently sneering at the poverty of their husbands' parents, endeavoring to pursue more garish lifestyles than others (余尝见取富室之女者, 骄奢淫佚, 颇僻自用, 动笑夫家之贫, 务逞华靡, 穷极奉养, 以图胜人) (Xie Zhaozhe, 2016). Dong Han (1624-1697), who wrote during the transition between the Ming and Qing dynasties, recorded in his San gang shi lüe (三冈识略) that one rascal, a destitute descendant of a renowned scholar, dug up the graves of his ancestors for treasure and carelessly discarded the remains (Dong Han, 2000). In China, ancestor worship had been a tradition for several thousand years, with strong support from Confucianism (Tang 1995: 274). Disturbing the graves of one's ancestors was an extreme offense. The recorded event demonstrates the collapse of social belief in Confucianism in this period.

Political chaos also aggravated moral degradation. In the Ming dynasty, conflicts between ministers and emperors were apparent. The emperors were infamous for their lazy administration (懒政). Lazy administration incurred denunciation from the ministers. One minister lamented that, for twenty years, the emperor had neglected ritual fetes, instruction in court, and inquiry and discussion face to face with the ministers (“二十年来, 郊庙、朝讲、召对、面议 俱废”) (Zhang Tingyu 2000: 4021). In addition, the vacancy of the first prime minister (宰相) post exacerbated the conflict between emperors and ministers. The first emperor of the Ming dynasty, Zhu Yuanzhang, ordered his successors to not appoint a first prime minister. Thus, there was no buffer or coordinator between the emperors and ministers. Therefore, a polarized political situation - with the emperors on one side and the ministers on the other - came into being. Additionally, the notion of "the people as the foundation" in the Ming dynasty exacerbated the conflicts between the emperors and ministers (Jia 2011).

In the pandemonium of this social transformation, guanxi as a new form of human connection became popular. As mentioned above, the cardinal interpersonal relationships, such as those between husband and wife, father and son, and emperor and minister, had ceased to follow the values and criteria of Confucianism; therefore, social connections through guanxi became the guiding principle in social networks, as guanxi offered social capital for financial gain (Smart 1993). More importantly, because guanxi is a reciprocal exchange (Horak \& Taube 2016: 599), the rigid social hierarchy must be broken 
Why Was It the Ming Dynasty that Engendered the Guanxi Motif in Fiction?

for the associated social capital to circulate. Hence, it was soon popular in Ming society, as reflected in Ming fiction.

Although guanxi was deemed a unique type of interpersonal connection, it had roots in and depended on Confucianism (Lin 2011: 442). To achieve their aims through guanxi, social actors had to adhere to Confucian rituals ( $l i$, 礼) superficially for instrumental purposes (Ruan 2017), though the inner moral values were neglected. Therefore, although guanxi seemingly relied on criteria and obligations defined by Confucianism, it actually served other instrumental purposes - obtaining unmerited resources. In other words, guanxi functioned through the misuse or disguise of traditional Confucian rituals. Noting the collapse of Confucianism in social morals, the Ming government endeavored to motivate different social strata to restore the status of Confucianism (Nie Chunyan 2015). However, the endeavor did not achieve its goal of social moral improvement in that commercial milieu with retrograded social morals. To the contrary, it only reinforced guanxi consciousness, because Confucianism is the root of guanxi.

Once the traditional Confucian rituals began to be misused or to exist in name only, hypocrisy and irony were inevitable, especially because most of the time, guanxi involved circumventing formal institutions in the name of Confucian rituals to gain undeserved resources at the expense of society. This satisfied the need for conflict in constructing literary plots. For example, in The Plum in the Golden Vase, Ximen Qing takes Cai Jing, a high official in court, as his adoptive father to reap the benefits of particularism and nepotism, though Cai Jing neither begot him nor brought him up. This social connection built on materialism does not create any real affection between them. When Ximen Qing dies, Cai Jing is indifferent upon hearing the news. To secure mutual help in the future, Ximen Qing and Hua Zixu vow to be sworn brothers, but Ximen Qing stealthily fornicates with Hua Zixu's wife, Li Pinger, and embezzles Hua Zixu's wealth with her help. For Ximen Qing, these quasi-kinship relations are only a way to gain resources. They do not involve honest affection; on the contrary, they are completely deceptive in nature.

Such quasi-family and quasi-kinship connections were not reliable, and neither were other types of guanxi disguised as so-called intimate relationships. Thus, guanxi became a distinct literary motif for exposing and satirizing the hypocrisy of interpersonal relationships and for criticizing social deterioration. As a tool for satirizing and exposing social turpitude and for creating plots, the guanxi motif was significant in shaping works of fiction. 
Money worship, power, and guanxi represented in fiction from the Ming dynasty

The Ming dynasty witnessed severe bureaucratic corruption because of Ming policy. First, low salaries and inadequate budgeting induced system corruption, which was impossible to eradicate (Ni \& Van 2006: 335; Quah 2013: 24). This entrenched corruption was reflected in many works of Ming fiction, among which The Plum in the Golden Vase is typical. Second, because of their low salaries, officials usually resorted to collusion with the merchant class. As a typical example, in the novel, Ximen Qing, a merchant, lends money to or bribes officials with small salaries. Such loans from merchants to officials exacerbated corruption. Hence, in the world depicted in The Plum in the Golden Vase, there is no justice through the formal and official legal system (Szonyi 2017).

The atmosphere of money worship worsened corruption in the Ming dynasty. The commercialism of this epoch was marked by economic globalization. With low-cost productivity, the Ming dynasty became an important driver of the global economy, bringing about the unprecedented prosperity of commercial enterprise and thus in demand for currency - silver, which "headed to China from all corners of the earth" (Flynn \& Girildez 1997: xviii). The commodity economy in Ming China flourished to such a degree that the value of silver currency in the Chinese market was double its value elsewhere (Flynn \& Girildez 1995: 206). Economic prosperity not only minted numerous nouveaux riches but also cultivated new customs, including money worship. The situation in Fujian Province epitomized this transformation in the social ethos. In the early Ming dynasty, the economy of Fujian Province was sluggish, and the social mood was traditional. Under the stimulus of the commercial economy and overseas trade, after the middle of the Ming dynasty, social customs in Fujian underwent transformation in the spheres of material culture, public ethics, and human relations, with extravagance and luxury prevailing (Hong 2008). Wealth rather than traditional Confucian values became the critical criterion for measuring one's stature or reputation.

Bureaucratic corruption and money worship resulted in acute deterioration in officialdom. Officialdom, filled with moneyed arrogance, "was like a market; therefore, the officials were like the traders in the market” (仕途如市, 入仕 者如往市中贸易) (Zhou Shunchang 2015: 254). In such a market, only those "who are frivolous, cunning, irritable and aggressive can advance their official rank” (唯佻狡躁竞者乃得进耳) (He Liangjun 1959: 89). Extortion, bribery, and corruption in officialdom were relentless in this period (Chen Maoshan 1989). The income obtained through corrupt means in the Ming and Qing dynasties was 14 and 22 times the official income, respectively (Ni \& 
Why Was It the Ming Dynasty that Engendered the Guanxi Motif in Fiction?

Van 2006). The deterioration of officialdom is also evident in " $\mathrm{t}$ ] he recorded impeachment cases" (Huang 1974: 49) and "the larger sums involved in the exposed cases” (Huang 1974: 279). Covetousness corroded Ming officialdom.

Guanxi, in this situation, became an easy way for officials to procure corrupt wealth. It facilitated collusion and complicity between corrupt officials and merchants. Through it, corrupt officials gained wealth, and merchants obtained resources and social status. Descriptions of Ximen Qing from Outlaws of the Marsh and The Plum in the Golden Vase indicate that his position as a middleman for officials earns him both money and prestige. Therefore, he is treated "with careful deference" in Outlaws of the Marsh and is "feared" by "everyone in the whole district" in The Plum in the Golden Vase. Guanxi, as an informal social institution, plays a critical role and is an active element in corrupt exchange (Li 2011). As a variant of social capital (Qi 2013), guanxi provides Ximen Qing a convenient way to improve his social status and earn economic profits. However, Ximen Qing's use of guanxi is immoral, as he earns undeserved profits at the price of damaging social equity. For example, he frees the murderer Miao Qing and frames the upright official through guanxi. His actions are diabolical but are covered up and upheld by sentimental and affectionate interpersonal connections, guanxi. For example, to maintain guanxi with high officials, Ximen Qing takes Cai Jing, the highest official with whom Ximen Qing curries favor, as his adoptive father. His intimate guanxi displayed through Confucian ritual provides a cover for his corrupt intentions. The interaction rituals of bribery guanxi are a type of moral performance used to justify immoral practice (Ruan 2019). In essence, Ximen Qing's guanxi is sinful and even wicked.

The villain Ximen Qing's ability to gain social status and fortune is inseparable from this context. The social decline of the Ming dynasty is the context of The Plum in the Golden Vase's creation. This era witnessed the fading of traditional Confucianism and the rise of the capitalist economy, which resulted in the transformation of customs, social turbulence, and corruption in officialdom. The harmonious interpersonal relationships of Confucianism were replaced by hypocritical and cold, benefits-based relationships. Malefactors, but not law-abiding people, could gain wealth easily. Officials embezzled and extorted money at the expense of society as a whole. Amidst such societal chaos, guanxi, the ubiquitous pattern of interpersonal relations that served as a disrupter in this social context, took center stage in society, inevitably creating unfairness and conflict. Realist fiction requires conflict to sustain plots and portrays social inequity; therefore, the guanxi motif received unprecedented attention in Ming fiction. 


\title{
Conclusion
}

Guanxi has existed in China for thousands of years due to the spread of Confucianism and is indispensable in daily life. However, the guanxi motif did not become a literary motif until the Ming dynasty. In Ming fiction, the guanxi motif attained sudden significance.

This article argued that three factors contributed to the rise of the guanxi motif in Ming fiction. First, the popularity of fiction contributed to the guanxi motif's ability to thrive. During the Ming dynasty, for the first time in Chinese literary history, fiction, especially realist fiction, which narrates social conflicts, became popular. Guanxi, as a conventional and quotidian informal social network, naturally became a distinct literary motif in Ming fiction because of its capacity to inspire conflict. Second, the observed deterioration of public morals with respect to interpersonal relationships enhanced the significance of the guanxi motif in Ming fiction. The Ming dynasty witnessed the collapse of Confucian values in human relationships. Traditional Confucian rituals related to interpersonal relationships became a cover for the use of guanxi to gain resources and thus incurred hypocrisy and satire. Such tangible deterioration of public morals with respect to interpersonal relationships incurred conflict and was necessarily used as a literary motif in Ming fiction to reflect this social change. Third, money worship and political corruption, which further deteriorated social morals, provided the perfect conditions for guanxi's active role in society. Commercial prosperity fostered an atmosphere of money worship. Because of Ming policies such as low salaries for officials and the lazy administration of the emperors, corruption was severe. Guanxi, connecting avaricious merchants and corrupt officials seeking pecuniary gain, played an active part and exacerbated the corruption, and some crimes resulting from guanxi even became public secrets. To expose this social turpitude and to satisfy the need for plot conflict, works of fiction made guanxi a central motif.

\author{
Ruihui Han \\ hanrh@jnu.edu.cn \\ Jinan University \\ CHINA
}

\section{Bibliography}

Aliyev, H. 2017. Informal Institutions in Azerbaijan: Exploring the Intricacies of Tapsh. Europe - Asia Studies, 69 (4), 594-613. https://doi.org/10.1080/0966813 6.2017.1329404

Bian, Y. 2018. The Prevalence and the Increasing Significance of Guanxi. - The China Quarterly, 235 (April), 597-621. https://doi.org/10.1017/S0305741018000541 
Why Was It the Ming Dynasty that Engendered the Guanxi Motif in Fiction?

Brandstaetter, T. 2011. Informal Institutions, Personalism and Organisational Behaviour in the Arab World and China (Wasta and Guanxi ). - Journal of Regional Development, 3, 70-82.

Brokaw, C. J., Chow, K. 2005. Printing and Book Culture in Late Imperial China (Vol. 27). Berkeley: Univ. of California Press.

Chen Maoshan. 1989. On the Social Morals in the Middle and Later Ming Dynasty (试论明代中后期的社会风气). - Shixue Jikan, 4, 31-40.

Chen, G. 2015. The Tradition of Emotive Writing in the Zhuangzi and Its Echoes in Later Generations. - Frontiers of Philosophy in China, 10 (3), 340-352.

Chen, X.-P., Chen, C. C. 2004. On the Intricacies of the Chinese Guanxi: A Process Model of Guanxi Development. - Asia Pacific Journal of Management, 21 (3), 305324. https://doi.org/10.1023/B:APJM.0000036465.19102.d5

Coles, W. 2016. Creating Literary Stories: A Fiction Writer's Guide. Bloomington: AuthorHouse.

Confucius. 2007. The Analects of Confucius. Trans. B. Watson. Columbia University Press.

Dong Han. 2000. san gang shi lüe (三冈识略). (Z. Zhi 致之, ed.). Shenyang: Liaoning Education Publishing House.

Farh, J.-L., Tsui, A. S., Xin, K., Cheng, B.-S. 1998. The Influence of Relational Demography and Guanxi: The Chinese Case. - Organization Science, 9 (4), 471488. https://doi.org/10.1287/orsc.9.4.471

Flynn, D. O., Girildez, A. 1995. Born with a "silver spoon": The origin of world trade in 1571. - Journal of World History, 201-221.

Flynn, D. O., Girịldez, A. 1997. Metals and Monies in an Emerging Global Economy. Variorum Publishing.

Gu Yanwu. 2014. The Explaination of Daily Understanding (日知录集释). Shanghai: Shuanghai Guji chubanshe.

Han Tongwen, Huang Lin. 1980. The Realism in Ming and Qing Fiction Theory (明清 小说理论中的现实主义问题). - Xueshu Yuekan, (11), 59-64.

He Liangjun. 1959. Book of Siyouzhai 《四友斋从说》. Beijing: China Publishing House.

He Qiaoyuan. 2004. Huozhiji in Mingshancang. 《名山藏・货殖记》. In Xie Guozhen (ed.), Selection of Economy History Material on Ming Society (Second Volumn)《明 代社会经济史料选编下》. Fuzhou: Fujian People's Publishing House.

Hitt, M. A., Lee, H.-U., Yucel, E. 2002. The importance of social capital to the management of multinational enterprises: Relational networks among Asian and Western firms. - Asia Pacific Journal of Management, 19 (2-3), 353-372.

Hong, H. 2008. The transformation of social customs in Ming Dynasty Fujian. Frontiers of History in China, 3 (4), 551-577. https://doi.org/10.1007/s11462-0080024-1

Horak, S., Klein, A. 2016. Persistence of informal social networks in East Asia: Evidence from South Korea. - Asia Pacific Journal of Management, 33 (3), 673-694. https://doi.org/10.1007/s10490-015-9416-1

Horak, S., Taube, M. 2016. Same but different? Similarities and fundamental differences of informal social networks in China (guanxi) and Korea (yongo). Asia Pacific Journal of Management, 33 (3), 595-616. https://doi.org/10.1007/ s10490-015-9452-x 
HAN

Hsia, C. 2016. The Classic Chinese Novel: A Critical Introduction. Chinese University Press.

Huang, R. 1974. Taxation and Governmental Finance in Sixteenth-Century Ming China (Vol. 4). New York: Cambridge University Press.

Hwang, K. 1987. Face and Favor: The Chinese Power Game. - American Journal of Sociology, 92 (4), 944-974. https://doi.org/10.1086/228588

Jia, L. 2011. Conflicts Between Monarch and Ministers. - Chinese Studies in History, 44 (3), 72-89. https://doi.org/10.2753/CSH0009-4633440304

Ju, Y. 1995. Communicating Change in China. - D. P. Cushman, S. S. King, eds., Communicating Organizational Change. New York: State University of New York Press, 227-249.

Lanlingxiaoxiaosheng. 2013. The Plum in the Golden Vase or, Chin P'ing Mei, Volume One: The Gathering. Trans. D. T. Roy. Princeton: Princeton University Press.

Ledeneva, A. 2003. Informal Practices in Changing Societies: Comparing Chinese Guanxi and Russian Blat. - Working Papers, 115 (26), 1013-1016.

Leung, T. K., Wong, Y. H. 2001. Guanxi Relationship Marketing in a Chinese Context. New York: International Business Press.

Li Chunfang. 2014. Rules of Local Custom 《乡约事谊》. In Niu Mingshi (ed.), Rules of Local Custom in Chinese History 《中国历代乡规民约》. Beijing: China Society Publishing House.

Li, L. 2011. Performing Bribery in China: Guanxi-practice, Corruption with a Human Face. - Journal of Contemporary China, 20 (68), 1-20. https://doi.org/10.1080/10 670564.2011.520841

Lin, L. H. 2011. Cultural and Organizational Antecedents of Guanxi: The Chinese Cases. - Journal of Business Ethics, 99 (3), 441-451. https://doi.org/10.1007/ s10551-010-0662-3

Luo, Y., Huang, Y., Wang, S. L. 2012. Guanxi and Organizational Performance: A Meta-analysis. - Management and Organization Review, 8 (1), 139-172. https:// doi.org/10.1111/j.1740-8784.2011.00273.x

Nadeem, S., Kayani, N. 2017. Sifarish: Understanding the Ethical Versus Unethical Use of Network-Based Hiring in Pakistan. - Journal of Business Ethics, 1, 1-14.

Ni, S., Van, P. H. 2006. High Corruption Income in Ming and Qing China. Journal of Development Economics, 81 (2), 316-336. https://doi.org/10.1016/j. jdeveco.2005.05.004

Nie, Chunyan. 2015. Confucianism Neo Confucianism Secular Utility and the Novels of the Ming and Qing Dynasties《论儒学、理学的世俗化、实用化与明清小说》. Journal of Tianjin University (Social Sciences), 3, 32-36.

Qi, X. 2013. Guanxi, Social Capital Theory and Beyond: Toward a Globalized Social Science. - British Journal of Sociology, 64 (2), 308-324.

Quah, J. S. T. 2013. Minimizing Corruption in China: Is This an Impossible Dream? Maryland Series in Contemporary Asian Studies, 4, 1.

Ruan, J. 2017. Interaction Rituals in Guanxi Practice and the Role of Instrumental Li. - Asian Studies Review, 41 (4), 664-678. https://doi.org/10.1080/10357823. 2017.1372363 
Why Was It the Ming Dynasty that Engendered the Guanxi Motif in Fiction?

Ruan, J. 2019. "Bribery with Chinese Characteristics" and the Use of Guanxi to Obtain Admission to Prestigious Secondary Schools in Urban China. - Critical Asian Studies, 51 (1), 120-130. https://doi.org/10.1080/14672715.2018.1548906

Shi, N. 1986. Outlaws of the Marsh. Trans. S. Shapiro. Sydney: Unwin Paperbacks.

Smart, A. 1993. Gifts, Bribes, and Guanxi : A Reconsideration of Bourdieu's Social Capital. - Cultural Anthropology, 8 (3), 388-408. https://doi.org/10.1525/can.1993. 8.3.02a00060

Szonyi, M. 2017. The Case in the Vase: What Can a Ming Novel Tell Us about Traditional Chinese Legal Culture? - Frontiers of History in China. 12 (4), 621-625

Tang, Z. 1995. Confucianism, Chinese Culture, and Reproductive Behavior. - Population and Environment, 16 (3), 269-284. https://doi.org/10.1007/BF02331921

Vonnegut, K. 2010. Kurt Vonnegut on the Shapes of Stories, http://www.youtube.com/ watch? $=0$ P3c1h8v2ZQ (22.05. 2019).

Wang, H. 2000. Informal Institutions and Foreign Investment in China. - The Pacific Review, 13 (4), 525-556. https://doi.org/10.1080/09512740010004269

Warren, D. E., Dunfee, T. W., Li, N. 2004. Social Exchange in China: The DoubleEdged Sword of Guanxi. - Journal of Business Ethics, 55 (4), 353-370. https://doi. org/10.1007/s10551-004-1526-5

Wong, Y. H., Leung, T. K. P., Hung, H., Ngai, E. W. T. 2007. A Model of Guanxi Development: Flexibility, Commitment and Capital Exchange. - Total Quality Management \& Business Excellence, 18 (8), 875-887. https://doi.org/10.1080/ 14783360701350607

$\mathrm{Wu}$, C. 1984. Journey to the West. (W. J. F. Jenner, trans.). Foreign Languages Press. Retrieved from Wu, J. S. (1969). Chinese language and Chinese thought. Philosophy East and West, 19 (4), 423-434. https://doi.org/10.2307/1397634

Wu, L. H. 1995. From Xiaoshuo to Fiction: Hu Yinglin's Genre Study of Xiaoshuo. - Harvard Journal of Asiatic Studies, 55 (2), 339-371. https://doi.org/10. $2307 / 2719346$

Xie Zhaozhe 2016. Wuzazu 《五杂沮》in Chinese TextProject(中国哲学书电子化计划), https://ctext.org/wiki.pl?if=gb\&chapter=65316\&remap=gb (14.11.2020).

Yen, D. A., Barnes, B. R., Wang, C. L. (2011). The Measurement of Guanxi: Introducing the GRX scale. - Industrial Marketing Management, 40(1), 97-108. https:// doi.org/10.1016/j.indmarman.2010.09.014

Zhai, Xuewei 2011. Perspectives on Chinese “Face" 《中国人的脸面观》. Beijing: Peking University Press.

Zhang Tingyu 2000. History of Ming《明史》. Volumn 5. Beijing: China Publishing House.

Zhang, Y., Zhang, Z. 2006. Guanxi and Organizational Dynamics in China: A Link between Individual and Organizational Levels. - Journal of Business Ethics, 67 (4), 375-392. https://doi.org/10.1007/s10551-006-9031-7

Zhou Shunchang 2015. Di hou jian Desheng zhuxiongdi《第后柬德升诸兄弟》. In Zhu Jianxin (ed.), Wanming xiaopin xuanzhu《晚明小品选注》. Hangzhou: Zhejiang People's Fine Arts Publishing House.

Zhuangzi 2001. Wai wu 《外物》. In Han Weizhi (ed.), Zhuangzi 《庄子》. Changchun: Jilin Wenshi Publishing House. 